As conclusion, we can say that collaborative filtering is really a very powerful tool that can be applied to almost any subject area. It will not only improve the user experience but will also distinguish the web resource from potential competitors. Depending on the specifics of the subject area, you should choose a filtering algorithm and determine the measure of similarity.

\title{
References:
}

1. D. Goldberg, D. Nichols, B. M. Oki, and D. Terry, «Using collaborative filtering to weave an information tapestry» Communications of ACM, 1992, vol. 35, no. 12 , pp. $61-70$.

2. G. Linden, B. Smith, and J. York, «Amazon.com recommendations: item-to-item collaborative filtering» IEEE Internet Computing, 2003, vol. 7, no. 1, pp. 76-80.

3. A. Ansari, S. Essegaier, and R. Kohli, «Internet recommendation systems» Journal of Marketing Research, 2000, vol. 37, no. 3, pp. 363-375.

\section{INNOVATIVE WAYS TO IMPROVE THE PRODUCTION TECHNOLOGY OF MEAT LOAVES}

\section{Tetiana Zhelieva ${ }^{1}$}

DOI: https://doi.org/10.30525/978-9934-588-39-6-37

Analyzing the food market of Ukraine, it should be noted that sausage products are in high demand and occupy a significant place in the consumer's food basket. Meat loaves are of particular interest in view of expanding the range and improving production technology. They are not only delicious and convenient to use, but also contain a large number of useful substances, which causes their popularity to increase every year [1].

Meat loaves belong to the group of cooked sausages and taste like cooked sausages, but they have a special taste due to baking. For the production of meat loaves, the same raw materials are used as for the production of cooked sausages beef, pork, lamb, lard, raw fat, dried meat mass, protein raw materials of animal and vegetable origin, starch, dairy products, eggs, wheat flour, and spices. Preparation of raw materials, pickles, grinding and cooking of minced meat is carried out similarly to the production of cooked sausages, except for the addition of less water (10...20\% by weight of cutterized raw materials). In general, meat loaves differ from cooked sausages in low humidity (by 2...3\%), are made without

\footnotetext{
${ }^{1}$ Kharkiv State University of Food Technology and Trade, Ukraine
} 
a shell and have the form of molded bread with a dark surface color due to the use of the baking process during production [2, p. 187].

Manufacturers of meat loaves often face a number of problems that directly affect the quality of the finished product, in particular, the instability of the meat emulsion and, as a result, the formation of bouillon edema, shrinkage, wrinkling of the surface, a large percentage of losses during heat treatment, etc.

Muscle proteins that perform water- and fat-retaining functions, responsible for the formation of high-viscosity solutions and thermotropic gels, are crucial in ensuring the stability of meat emulsions. However, even the maximum amount of protein does not always solve the problem of stability of minced emulsions. The situation is also complicated by the need to include fat raw materials in loaf recipes, reducing the permissible level of phosphate use and, often, by the impossibility of additional introduction of plant or animal proteins [3, p. 11; 4, p. 25]. Therefore, maintaining the stability of meat emulsions becomes a problem for technologists and determines the continuous search for new technologies, modernization of production facilities.

Given the above, we can conclude that the problem of improving the technology of meat loaves is multifaceted and requires the use of certain technological innovations. One of these innovations is the use of the «KrioMeat» mixture in the production of meat loaves. The effective action of the mixture developed by specialists of the Kharkiv State University of Food Technology \& Trade has been proven in the production of semi-finished frozen split meat products [5, p. 29]. It was found that the use of the mixture contributes to an increase in the moisture binding capacity and solubility of proteins, reducing losses during freezing and heat treatment, improving the rheological and organoleptic characteristics of products [6, p. 70; 7, p. 33].

The active ingredients of the mixture are food ingredients of polysaccharide nature (hydrocolloids) [5, p. 29]. Some hydrocoloids, due to their structural features, are able to form strong hydrogen bond ions resistant to high temperatures. When solutions based on them are heated, they do not transform into a liquid state, but on the contrary, they are compacted and retain their texture after cooling [4, p. 26]. Therefore, we believe that the use of the «KrioMeat» mixture in the production of meat loaves is relevant and promising.

In order to improve the production technology of meat loaves and the formation of technological aspects of the «KrioMeat» mixture use in their composition, we studied the influence of heat processing on organoleptic parameters, in particular the structural properties (consistency), of the «KrioMeat» hydrated mixture, solutions of which were prepared on the basis of the manufacturer's recommendations. For the solution, we used drinking water with a temperature of $12 \pm 2^{\circ} \mathrm{C}$ in amount of $35 \mathrm{~g}$ to $2.5 \mathrm{~g}$ of dry mixture. After mixing, the mass became viscous and fluid, as shown in Figure 1. 

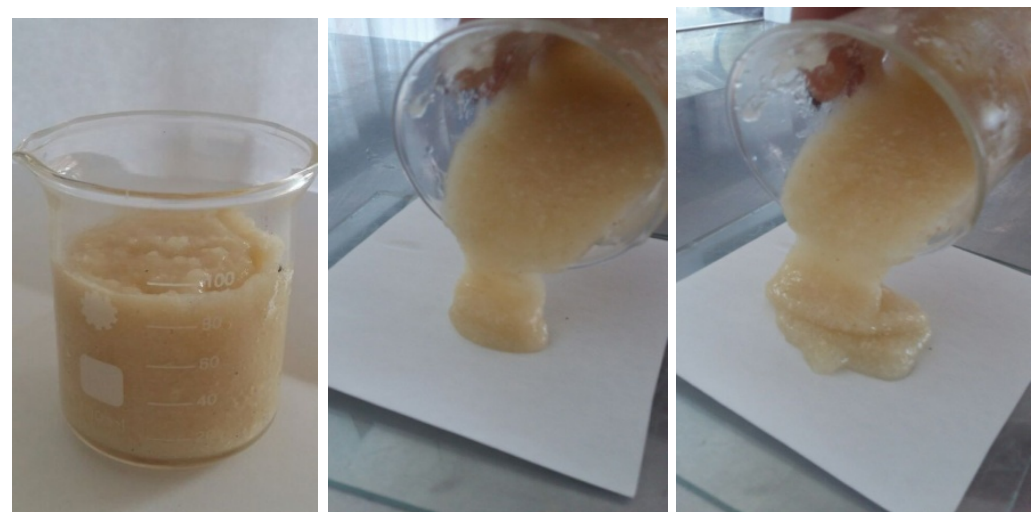

Figure 1. Hydrated «KrioMeat» mixture after cooking

The duration of the technological process of meat loaves production in general takes 30 minutes, so the mass was kept for 30 minutes at a temperature of $14 \pm 2^{\circ} \mathrm{C}$. Such exposure led to a complete swelling of the components of the mixture, but the mass did not significantly change its parameters - more viscous, but fluid (Figure 2).
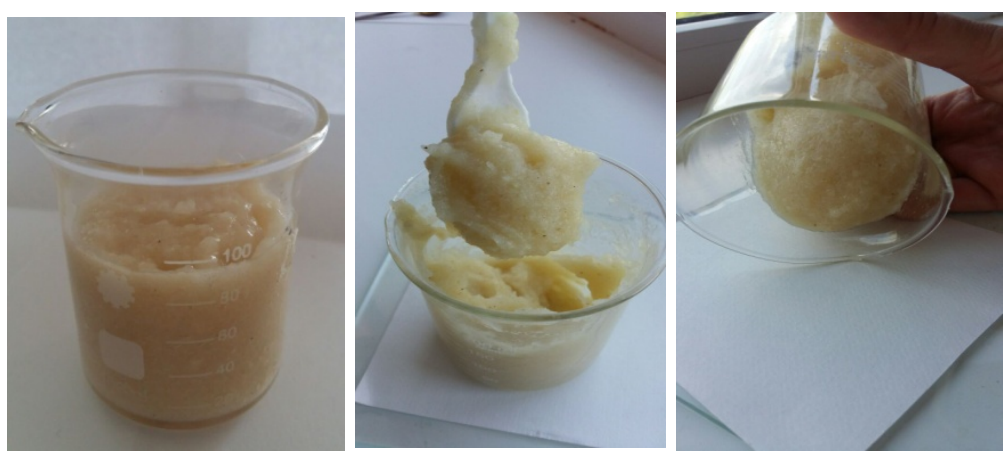

Figure 2. Hydrated «KrioMeat» mixture after exposure

Subsequent heat treatment of the mass in a water bath at a temperature of $130^{\circ} \mathrm{C}$ for 150 minutes (based on the modes and parameters of heat treatment of meat loaves) indicated not only the preservation of the previously obtained texture, but also its compaction, both hot and cooled (Figure 3). 

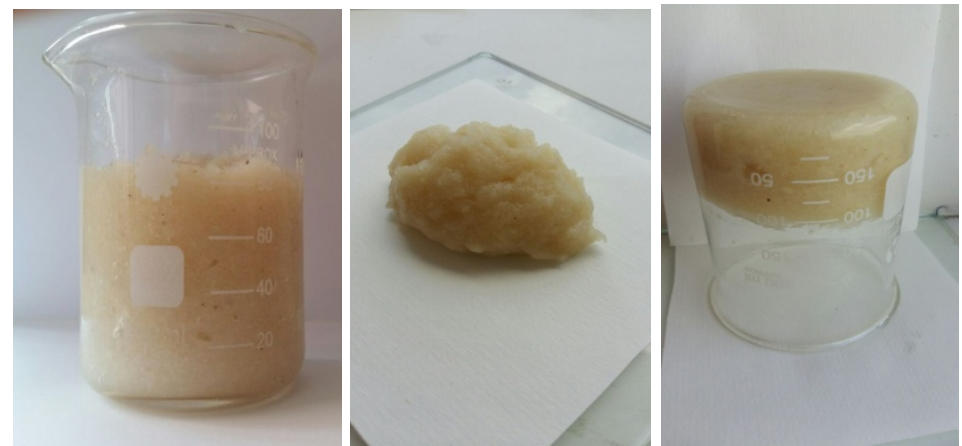

Figure 3. Hydrated «KrioMeat» mixture after heat processing

The effect of the «KrioMeat» mixture on the emulsifying ability and stability of the minced meat loaf emulsion was also studied. The mixture was introduced in a hydrated form in the amount of $1 . . .3 \%$ by weight of raw meat. The need to conduct these studies is due to the fact that emulsions are thermodynamically unstable systems and over time they can be subject to sedimentation, flocculation and coalescence of the fat phase. It was found that the use of the «KrioMeat» mixture in the composition of minced meat provides an increase in the emulsifying capacity by $38 . . .45 \%$, and the stability of the emulsion is $98.2 . . .99 .4 \%$.

Thus, the conducted research allows to conclude that a high-temperature heat processing does not affect organoleptic properties, in particular structural ones, of the mixture «KrioMeat», and its use in the composition of mince for meat loaf production will increase its emulsifying ability and emulsion stability. We further research in this direction relevant and promising, and the use of this mixture will expand the range, increase output and reduce the cost of production.

\section{References:}

1. Pro-Consulting (2019). Analiz rynka varenoy kolbasy, sosisok $i$ sardelek. 2019 god [Market analysis of cooked sausages, sausages and sausages. 2019 year]. Kyiv: Pro-Consulting. Retrieved from: https://pro-consulting.ua/issledovanierynka/analiz-rynka-varenoj-kolbasy-sosisok-i-sardelek-2019-god

2. Rogov, I. A., Zabashta, A. G., \& Kazyulin, G. P. (2009). Spravochnik tekhnologa kolbasnykh izdeliy [Handbook of sausage technologist]. Moscow: Kolos. (in Russian)

3. Vinnikova, L. G. (2000). Teorija i praktyka pererobky m'jasa [Theory and practice of meat processing]. Ishmael: SMIL. (in Ukrainian) 
4. Kozeeva, O. V., Osipova, E. S., \& Datsko, V. A. (2013). Funktsional'nye smesi s gidrokolloidami dlya varenykh kolbas [Functional mixtures with hydrocolloids for cooked sausages]. Meat industry, no. 7, pp. 25-27. (in Ukrainian)

5. Zhelieva, T. S., Yancheva, M. O., \& Bolshakova, V. A. (2018). Sumishi «KrioMeat» u tekhnologhijakh vyrobnyctva napivfabrykativ m'jasnykh posichenykh zamorozhenykh [ «KrioMeat» in the technology of production of frozen food products]. Proceedings of the The development of technical sciences: problems and solutions (Czech Republic, Brno, April 27-28, 2018). Riga: Baltija Publishing, pp. 29-32. (in Ukrainian)

6. Yancheva, M. O., \& Zhelieva, T. S. (2015). Funkcionaljno-tekhnologhichni vlastyvosti m'jasnykh modeljnykh system z vykorystannjam sumishej krioprotektornoji diji [Functional and technological properties of meat model systems using cryoprotective mixtures]. Food Science and Technology, vol. 1, no. 30, pp. 70-74. (in Ukrainian)

7. Yancheva, M. O., \& Zhelieva, T. S. (2015). Vplyv zamorozhuvannjarozmorozhuvannja na bilkovu skladovu ta mikrostrukturu m'jasnykh system [The effect of freezing-thawing on the protein component and microstructure of meat systems]. The agro-food industry, no. 3, pp. 33-37. (in Ukrainian)

\section{WELDING-TECHNOLOGICAL PROPERTIES OF SLAG SYSTEMS OF FLUX-CORED WIRE}

\section{Mykola Kakhovskyi ${ }^{1}$ Yurii Kakhovskyi ${ }^{2}$}

DOI: https://doi.org/10.30525/978-9934-588-39-6-38

One of the way to increase the productivity of welding is using a mechanized flux-cored wire welding. The main difference between flux-cored wire and solid wire is the powder core, which includes alloying, stabilizing, gas- and slag-forming components.

Flux-cored wires have several advantages, such as high surfacing/welding speed, high productivity, the ability to weld in open areas with wind or even under water (for self-shielding wires), the ability to provide any type of alloying, additional desulfurization of the weld metal, etc. [1, p. 84; 2, p. 16].

The main factor, which provides the special properties of flux-cored wire, is a slag-forming system, which volume can reach up to $70 \%$ of the weight of the wire.

Adding of slag-forming and deoxidizing components into the flux-core of the wire makes it possible to deoxidize the weld metal pool, intensively treat it

\footnotetext{
${ }^{1}$ Paton Electric Welding Institute, Ukraine

${ }^{2}$ Paton Electric Welding Institute, Ukraine
} 